\title{
Localization of the MAGE1 gene encoding a human melanoma antigen to chromosome $\mathrm{Xq28}$
}

\author{
M.G. Wang, ${ }^{1}$ R. Zakut, ${ }^{2}$ H. Yi, ${ }^{1}$ S. Rosenberg, ${ }^{2}$ and O.W. McBride ${ }^{1}$ \\ ${ }^{1}$ Laboratory of Biochemistry and 2 Surgery Branch, National Cancer Institute, National Institutes of Health, Bethesda MD
}

\begin{abstract}
MAGE1 encodes a tumor specific antigen MZ2-E that elicited a cytotoxic T lymphocytic response (CTL) in the patient from whom it was derived. In this study, cDNA and genomic probes have been used to localize this gene by Southern analysis of a human-rodent somatic cell hybrid panel. The probes detect a small multigene family, and both MAGE1 and
\end{abstract}

several other members of this family are located on the long arm of the human X chromosome. A cosmid with a 12-kb insert including the entire MAGE1 gene was biotinylated and used to further localize the gene to Xq28 by in situ hybridization of metaphase spreads. The function of this antigen in normal cells and tumor cells currently remains unclear.
MAGE1 encodes a human melanoma associated antigen MZ2-E (Van Der Bruggen et al., 1991). It belongs to a multigene family whose members show a high degree of homology (Van der Bruggen et al., 1991). These genes are differentially expressed in transformed but not in normal dividing cell lines (Van der Bruggen et al., 1991; Zakut and Rosenberg, 1993; Rimoldi et al., 1993) suggesting that they may be linked to the transformation event.

In order to identify a possible role of MAGE1 in melanomas, the chromosomal location of the gene was determined. The gene is located on the distal end of the long arm of the X chromosome (Xq28). Although several members of the MAGE multigene family are also located on $\mathrm{Xq}$, they do not appear to be tandemly linked to MAGE1.

The MCF2 protooncogene is located at Xq26.3 $\rightarrow \mathrm{q} 27.1$ (Tronick et al., 1989; Schlessinger et al., 1991), but no known tumor suppressor genes or protooncogenes have been previously assigned to $\mathrm{Xq} 28$. Hence, localization of this gene provides no evidence that it has any role in melanoma tumor development. In contrast, genetic linkage studies of familial melanoma suggests that recessive tumor suppressor gene(s) may be in-

\footnotetext{
Received 10 February 1994; manuscript accepted 25 March 1994.

Request reprints from Dr. O. Wesley McBride, Laboratory of Biochemistry, National Cancer Institute, NIH, Bethesda MD 20892; telephone: 301-496-5520; fax: 301-402-3095.

Present address of R.Z.: Chemical Immunology Dept., Weizmann Institute of Science, Rehovot 76100 , Israel.
}

volved, and the genes have been reported to be located on 9p22 $\rightarrow$ p1 3 (Cannon-Albright et al., 1992; Nancarrow et al., 1993) and possibly also 1 p36 (Goldstein et al., 1993).

\section{Materials and methods}

\section{Cell hybrids and filter hybridization}

A panel of human/rodent somatic cell hybrids segregating human chromosomes has been described (McBride et al., 1982). The human chromosome content of each hybrid cell line has been determined by standard isozyme analysis, Southern analysis with probes from previously localized genes, and cytogenetic analysis. Standard conditions were used for preparing Southern blots of DNA restriction digests on positively charged nylon membranes and for blot hybridization and washing under stringent conditions that allowed no more than $10 \%$ divergence of hybridizing sequences (Olson et al., 1991).

\section{Probes}

Cosmid B3, containing the entire MAGE1 gene in a 12-kb insert (van der Bruggen et al., 1991), was a generous gift from Dr. T. Boon, Ludwig Institute for Cancer Research, Brussels, Belgium. Cosmid B3 was labeled with biotin14-dATP by nick-translation and used as a probe for FISH.

Probes for Southern blotting were labeled to high specific activity $\left(>10^{9}\right.$ $\mathrm{cpm} / \mu \mathrm{g}$ DNA) with ${ }^{32} \mathrm{P}-\mathrm{dCTP}$ by random hexanucleotide primed synthesis (Feinberg and Vogelstein, 1983). DNA fragments used to prepare ${ }^{32} \mathrm{P}$-labeled probes were (1) a 2.4-kb BamHI genomic fragment containing MAGE1 exons 2 and 3 (including the entire coding region), and (2) a 500-bp cDNA coding sequence obtained by PCR amplification of MAGE1 cDNA using primers CHO-8 at nucleotide 166 and $\mathrm{CHO}-9$ at nucleotide 658 (van der Bruggen et al., 1991); identical patterns of hybridization were obtained with both probes. A 490-bp ApaI-ScaI fragment was used to prepare a 3'-untranslated probe which included 20 bp of coding sequence (Fig. 1). 


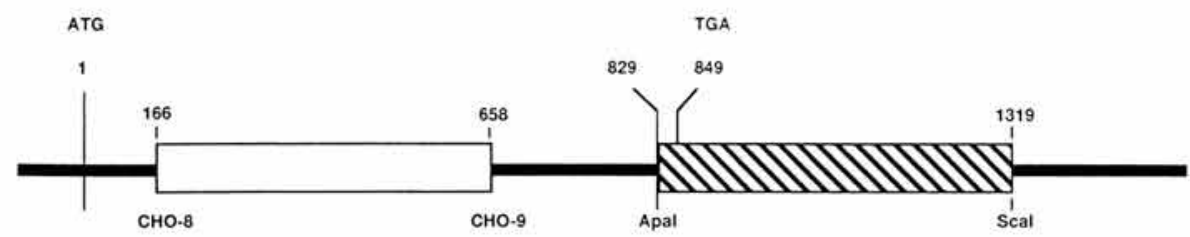

Fig. 1. Organization of MAGE1 cDNA used for preparation of probes. Numbering starts at the initiation codon ATG (\#1). The termination codon TGA is at nucleotide 849. CHO-8 and CHO-9 are oligonucleotide primers used for the amplification of part of the coding region (open box). Apa-1/Sca-1 fragment was used as a probe for the 3'-untranslated region (hatched box).

\section{In situ hybridization}

Experiments were performed as described (Kim et al., 1992) using peripheral blood lymphocytes from a normal male (46; XY) stimulated with phytohemagglutinum $(0.5 \mu \mathrm{g} / \mathrm{ml})$ and synchronized by addition of BrdU for $16 \mathrm{~h}$. The metaphase spreads were denatured with $0.07 \mathrm{~N} \mathrm{NaOH}$ in $64 \%$ ethanol. Biotinylated probe $(20 \mathrm{ng} / \mu \mathrm{l})$ and HeLa DNA $(1 \mu \mathrm{g} / \mu \mathrm{l})$ were dissolved in hybridization solution $(50 \%$ formamide, $2 \times$ SSCP, $10 \%$ dextran sulfate), denatured $10 \mathrm{~min}$ at $70^{\circ} \mathrm{C}$, reassociated for $40 \mathrm{~min}$ at $37^{\circ} \mathrm{C}$, and hybridized with the metaphase chromosomes for $16-20 \mathrm{~h}$. Hybridization was detected after three to five cycles of treatment with FITC-avidin $(5 \mu \mathrm{g} /$ $\mathrm{ml})$ and biotinylated goat antiavidin $(5 \mu \mathrm{g} / \mathrm{ml})$. Metaphase chromosomes were banded by treatment with Hoechst $33258(150 \mu \mathrm{g} / \mathrm{ml})$ for $30 \mathrm{~min}$ followed by illumination with long wave length light $(365 \mathrm{~nm})$ and final treatment with FITC-avidin and propidium iodide. Using a Leitz microscope with epifluorescence optics, FITC signals were observed and photographed with a blue filter ( $490 \mathrm{~nm}$ excitation and $510 \mathrm{~nm}$ emission), and banded chromosomes were observed with a violet filter $(365 \mathrm{~nm}$ excitation and $460 \mathrm{~nm}$ emission). Photographs were projected and superimposed to permit alignment of the hybridization signal with the chromosome bands.

\section{Results and discussion}

MAGE1 and a small group of related sequences were localized to the human $\mathrm{X}$ chromosome by Southern analysis of hybrid panel DNA digested with EcoRI (Table I). A series of 5 or 6 hybridizing bands (Fig. 2A) cosegregated with the X-chromosome, and segregated discordantly ( $\geq 36 \%)$ with other human chromosomes. This localization was confirmed by detection of these genes in a human/mouse hybrid containing only the human $X$ chromosome and a portion of chromosome $2 p$ and in another human/hamster hybrid containing only human chromosomes 22,6pter $\rightarrow \mathrm{q13}$, and $\mathrm{X}$. The gene was further localized by analysis of hybrids containing well-characterized translocations involving the $\mathrm{X}$ chromosome. One series of human-hamster hybrids (McBride et al., 1982b) was isolated after fusion of human fibroblasts (GM0073) containing a reciprocal X;14 (q13;q32) chromosome translocation (Fig. 2A). Three independent hybrids retaining only the Xpter $\rightarrow \mathrm{q} 13$ translocation chromosome in the absence of the normal $\mathrm{X}$ or the reciprocal translocation chromosome did not contain the MAGE genes whereas these genes were present in ten independent hybrids retaining only the $\mathrm{Xq} 13 \rightarrow$ qter translocation chromosome.

DNAs isolated from a series of mouse cell lines containing smaller regions of the human $\mathrm{X}$ chromosome following chromosome-mediated gene transfer (Olsen et al., 1981) were also examined (Fig. 2B). One hybrid retaining the entire long arm of
Table I. Segregation of MAGE1 with the human X-chromosome

\begin{tabular}{|c|c|c|c|c|c|}
\hline \multirow{2}{*}{$\begin{array}{l}\text { Human } \\
\text { Chromosome }\end{array}$} & \multicolumn{4}{|c|}{ Gene/Chromosome } & \multirow{2}{*}{$\begin{array}{l}\% \\
\text { Discordancy }\end{array}$} \\
\hline & $+1+$ & $+1-$ & $-1+$ & $-1-$ & \\
\hline 1 & 19 & 28 & 11 & 25 & 47 \\
\hline 2 & 15 & 32 & 10 & 26 & 51 \\
\hline 3 & 20 & 27 & 6 & 30 & 40 \\
\hline 4 & 32 & 15 & 15 & 21 & 36 \\
\hline 5 & 18 & 29 & 5 & 31 & 41 \\
\hline 6 & 28 & 19 & 16 & 20 & 42 \\
\hline 7 & 20 & 27 & 18 & 18 & 54 \\
\hline 8 & 21 & 26 & 11 & 25 & 45 \\
\hline 9 & 19 & 28 & 11 & 25 & 47 \\
\hline 10 & 11 & 36 & 4 & 32 & 48 \\
\hline 11 & 23 & 24 & 7 & 29 & 37 \\
\hline 12 & 18 & 29 & 8 & 28 & 45 \\
\hline 13 & 18 & 29 & 15 & 21 & 53 \\
\hline 14 & 32 & 15 & 20 & 16 & 42 \\
\hline 15 & 27 & 20 & 17 & 19 & 45 \\
\hline 16 & 25 & 22 & 11 & 25 & 40 \\
\hline 17 & 30 & 17 & 22 & 14 & 47 \\
\hline 18 & 24 & 23 & 16 & 20 & 47 \\
\hline 19 & 16 & 31 & 11 & 25 & 51 \\
\hline 20 & 25 & 22 & 12 & 24 & 41 \\
\hline 21 & 35 & 12 & 18 & 18 & 36 \\
\hline 22 & 20 & 27 & 6 & 30 & 40 \\
\hline$X$ & 47 & 0 & 0 & 36 & 0 \\
\hline
\end{tabular}

MAGE1 cDNA and genomic probes detected 19-, 14-, 9-, 8-, and 3.6-kb bands in $E c o$ RI digests of hybrid DNAs after Southern hybridization. No cross-hybridizing rodent bands were observed (Fig. 1). Detection of the human gene is correlated with the presence or absence of each human chromosome in the group of somatic cell hybrids. Discordancy indicates the presence of the gene in the absence of the chromosome $(+/-)$ or absence of the gene despite the presence of the chromosome $(-1+)$, and the sum of these numbers divided by total hybrids examined $(\times 100)$ represents the percent discordancy. There were 29 primary human-hamster hybrids with 13 subclones ( 29 positive of 42 total) and 15 primary human-mouse hybrids with 26 subclones ( 18 positive of 41 total). The genes could be sublocalized to Xq13 $\rightarrow$ qter by examination of hybrids containing specific translocations (see text).

the $\mathrm{X}$ chromosome and another hybrid (A9S2) retaining about the distal one-third of the $\mathrm{X}$ chromosome including the hypoxanthine phosphoribosyltransferase gene (HPRT, Xq26) and the glucose-6-phosphate dehydrogenase gene (G6PD, Xq28) both retained the 2.4-kb BamHI hybridizing MAGE1 band as well as the related hybridizing MAGE sequences. Another cell line (JB3-1) contained HPRT and a similar amount of total human DNA located on at least two separate small X-chromosomal fragments; the distal portion of Xq including the G6PD locus was absent in this cell line. Of interest was the fact that this cell line (JB3-1) did not contain the 2.4-kb BamHI band 


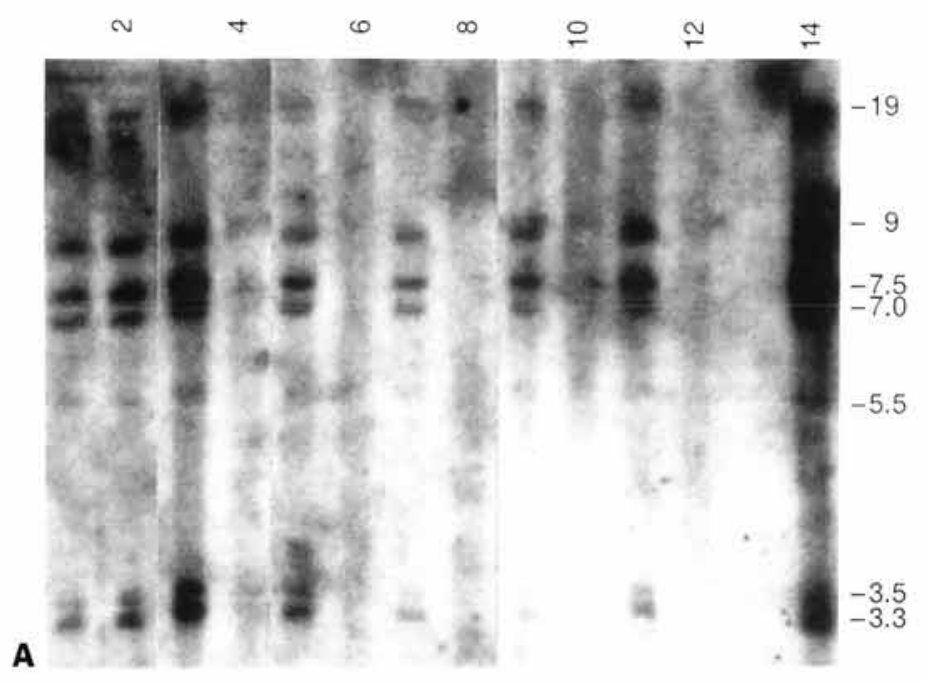

BamHI

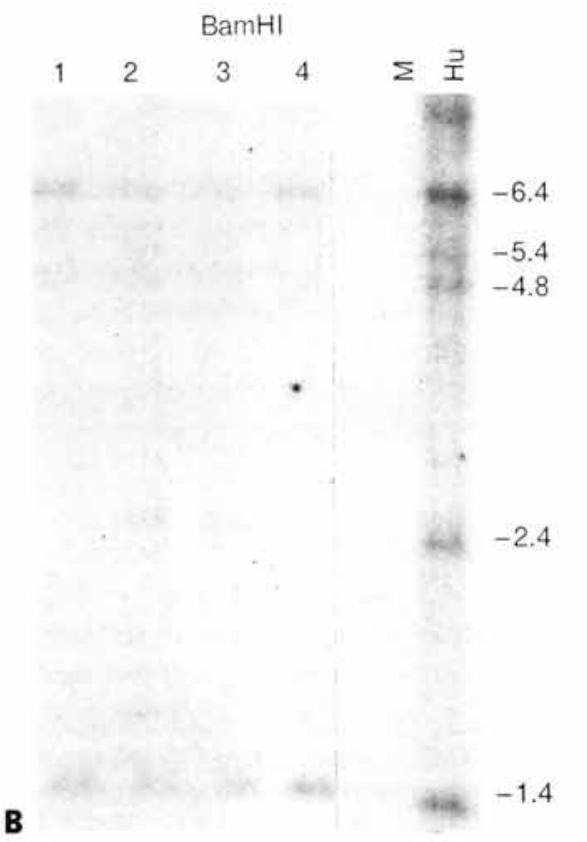

Fig. 2. (A) Southern hybridization of EcoR1 digested human/hamster hybrid DNA with MAGE1 cDNA. Lanes 1, 2, 3, 9, and 11 are independent hybrids which contain the $\mathrm{Xq13} \rightarrow$ qter translocation chromosome and the hybridizing MAGE bands whereas lanes 4, 10, and 12 show the same hybrids after loss of the $\mathrm{X}$ translocation chromosome and MAGE sequences. Lanes 5 and 7 are hybrids that contain both the $\mathrm{Xq} 13 \rightarrow \mathrm{qter}$ and $\mathrm{Xpter} \rightarrow \mathrm{q} 13$ translocation chromosomes. Lanes 6 and 8 are the same hybrids after loss of the $\mathrm{Xq13} \rightarrow$ qter translocation chromosomes. Lane 13 is parental hamster DNA and lane 14 is human placental DNA. (B). Southern hybridization of MAGE1 cDNA probe with BamHI digests of murine cell lines containing fragments of the human $\mathrm{X}$ chromosome. Control lanes are human placental DNA (Hu), mouse DNA (M), lane 2 contains complete human Xq in mouse background. Lane 3 (A9S2) contains the 2.4-kb MAGE1 band whereas lanes 1 (JB3-1T) and lane 4 (JB3-1H) do not contain the 2.4-kb band but the other hybridizing MAGE sequences are retained.

representing the authentic MAGE1 gene but the other hybridizing bands of the MAGE multigene family were present. These results strongly suggest that these related sequences are located on the distal region of $\mathrm{Xq}$ but they are dispersed over a rather large region and the genes are not tandemly linked.
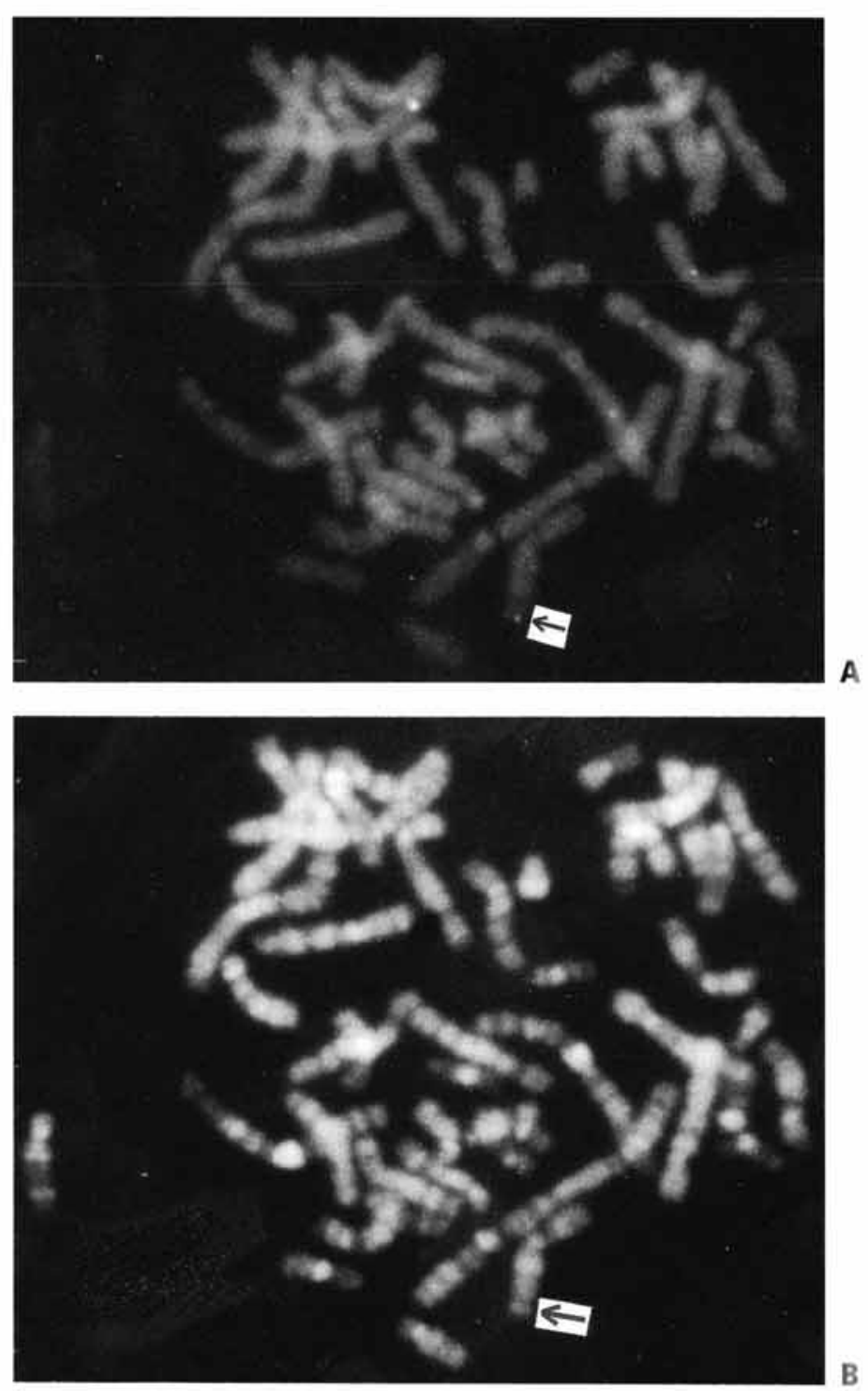

Fig. 3. In situ hybridization with MAGE1 probe, cosmid B3. (A) Typical metaphase spread showing fluorescent hybridization signal on both chromatids at Xq28. (B) Photograph of the same metaphase spread showing the fluorescent $\mathrm{G}$-banding pattern.

Cosmid B3 containing a $12-\mathrm{kb}$ insert including the entire 2.4-kb MAGE1 gene was labeled with biotin and used as a probe to further localize the gene by FISH (Fig. 3). The fluorescent signal could be localized on both chromatids at Xq28 near the border with Xq27 and was at the same location in all 39 metaphases examined. The precise location of the other MAGE related sequences on $\mathrm{Xq}$ could not be determined since a genomic probe for these sequences is currently unavailable.

Van der Bruggen et al. (1991) have shown that at least two other members of the MAGE multigene family are expressed in some tumors, and MAGE2 and MAGE3 transcripts were partially characterized using RT-PCR methods. It is probable that these functional genes may represent some of the cross-hybridizing bands which we observe in genomic digests. As one means 
of obtaining further information, we used a 490-bp cDNA fragment consisting almost exclusively of 3 -untranslated sequence as a probe on blots of genomic DNA restriction digests (Fig. 1). Surprisingly, a series of hybridizing bands was still detected at high stringency (i.e., washed at $55^{\circ} \mathrm{C}$ in $0.1 \times \mathrm{SSC}$ with $0.2 \%$ SDS); the size of these bands in BamHI digests was 2.4, 4.9, 6.9, 10.8 , and $14.7 \mathrm{~kb}$. When the blots were rewashed at $65^{\circ} \mathrm{C}$ in 0.1 $\times$ SSC with $0.2 \%$ SDS, only the 2.4 -kb hybridizing band persisted in Bam HI digests and only a single band in the other digests. These results would suggest that reduplication of the genes to form a multigene family has probably occurred relatively recently despite the fact that the genes seem to be located some distance from one another.

Efforts were made to detect DNA polymorphisms. No RFLPs were detected on examining twelve different restriction digests (EcoRI, BamHI, HindIII, XbaI, SacI, TaqI, PvuII, PstI,
$B g / \mathrm{II}, \mathrm{MspI}, E c o \mathrm{RV}$, and $K p n \mathrm{I})$ of DNAs from ten unrelated individuals.

Finally, melanomas are known to have complex karyotypes, and chromosomes 1, 6, 7, and 9 are those most frequently altered in malignant melanomas (Trent et al., 1989; Mitelman, 1991). Loss of chromosome $6 \mathrm{q}$ is the most frequent event followed by loss of 1p (Seizinger et al., 1991). To determine whether MAGE genes are present on any of these chromosomes, we undertook chromosomal localization of this family of genes. Our results indicate that MAGE1 is present on Xq28, and most other members of this multigene family also appear to be located on distal $\mathrm{Xq}$. The $\mathrm{X}$ chromosome is least often affected in human melanomas, and there is currently no evidence that the MAGE genes have any vital role in tumorigenesis. However, the antigens encoded by these genes are still of considerable interest as targets for immunotherapy.

\section{References}

Boon T. Teaching the immune system to fight cancer. Scientific American, March pp 82-89 (1993).

Cannon-Albright LA, Goldgar DE, Meyer LJ, Lewis $\mathrm{CM}$, Anderson DE, Fountain JW, Hegi ME, et al. Assignment of a locus for familial melanoma MLM, to chromosome $9 \mathrm{pl} 3 \rightarrow 22$. Science 258 : $1148-1152$ (1992)

Feinberg AP, and Vogelstein B: A technique for labeling DNA restriction endonuclease fragments to high specific activity. Analyt Biochem 132:6-13 (1983).

Goldstein AM, Dracopoli NC, Ho EC, Fraser MC, Kearns KS, Bale SJ, McBride OW, et al.: Further evidence for a locus for cutaneous malignant melanoma-dysplastic nevus (CMM/DN) on chromosome $1 \mathrm{p}$, and evidence for genetic heterogeneity. Am J hum Genet 52:537-550 (1993).

Kim IG, McBride OW, Wang M, Kim SY, Idler WW, Steinert PM: Structure and organization of the human transglutaminase I gene. J biol Chem 267: 7710-7717 (1992)

McBride OW, Battey J, Hollis GF, Swan DC, Siebenlist $\mathrm{U}$, Leder P. Localization of human variable and constant region immunoglobulin heavy chain genes on subtelomeric band $\mathrm{q} 32$ chromosome 14 . Nucl Acids Res 10:8155-8170 (1982b).
McBride OW, Heiter PA, Hollis GF. Swan D, Otey MC, Leder P. Chromosomal location of human kappa and lambda immunoglobulin light chain constant region genes. J exp Med 155:1480-1490 (1982).

Mitelman F: Catalog of Chromosome Aberrations in Cancer, 4th Ed. (Wiley-Liss, New York 1991).

Nancarrow DJ, Mann GJ, Holland EA, Walker GJ, Beaton SC, Walters MK, Luxford C, et al.: Confirmation of chromosome 9p linkage in Familial Melanoma. Am J hum Genet 53:936-942 (1993).

Olsen AS, McBride OW, Moore DE: Number and size of human X chromosome fragments transferred to mouse cells by chromosome-mediated gene transfer. Mol cell Biol 1:439-448 (1981).

Olson S, Wang MG, Carafoli E, Strehler EE, McBride OW: Localization of two genes encoding plasma membrane $\mathrm{Ca}^{2+}$ transporting ATPases to human chromosomes $1 \mathrm{q} 25 \rightarrow \mathrm{q} 32$ and $12 \mathrm{q} 21 \rightarrow \mathrm{q} 23$. Genomics 9:629-641 (1991),

Rimoldi D, Romero P, Carrel S: The human melanoma antigen-encoding gene, MAGE1, is expressed by other tumor cells of neuroectodermal origin such as glioblastoma and neuroblastomas. Int J Cancer 54: 527-528 (1993)
Schlessinger D, Little RD, Freije D, Abidi F, Zucchi I, Porta G, Pilia G, Nagaraja R, Johnson SK, Yoon JY: Yeast artificial chromosome-based genome mapping: some lessons from Xq24 $\rightarrow$ q28. Genomics 11:783-793 (1991).

Seizinger BR, Klinger HP, Junien C, Nakamura Y, Le Beau M, Cavenee W, Emanuel B, et al. Report of the committee on chromosome and gene loss in human neoplasia. Cytogenet Cell Genet 58:10801096 (1991).

Trent JM, Leong SP, Meyskens FL: Chromosome alterations in human malignant melanoma. Carcinog Compr Surv 11:165-186 (1989)

Tronick SR, McBride OW, Popescu NC, Eva A: Chromosomal localization of DBL oncogene sequences. Genomics 5:546-553 (1989).

Van der Bruggen P, Traversari C, Chomez P, Lurquin C, De Plaen E, Van den Eynde B, Knuth A, and Boon T. A gene encoding an antigen recognized by cytolytic $\mathrm{T}$ lymplocytes on a human melanoma. Science 254:1643-1647 (1991).

Zakut R, Topalian SL, Kawakami Y, Mancini M, Eliyahu S, Rosenberg SA: Differential expression of MAGE1, -2 , and -3 messenger RNA in transformed and normal human cell lines. Cancer Res $53: 5-8(1993)$. 